\title{
Aplikasi Sistem Informasi Museum Negeri Provinsi Sumatera Utara Berbasis Android
}

\author{
Bakti Das Eger Damanik', Wasit Ginting ${ }^{2}$ \\ ${ }_{1,2}$ Universitas Katolik Santo Thomas, Jln. Setia Budi No.479-F Medan, 061-8210161, Indonesia
}

\begin{tabular}{l} 
ARTICLE INFORMATION \\
\hline Received: Agustus 28,2019 \\
Revised: September 22,2019 \\
Available online: Oktober 05,2019 \\
KEYWORDS \\
\hline Aplikasi Sistem Informasi Museum Negeri \\
Provinsi Sumatera Utara Berbasis Android.. \\
CORRESPONDENCE \\
\hline Phone: +6285358014334 \\
E-mail: baktidamanik@gmail.com \\
\hline
\end{tabular}

\section{A B S T R A K}

Saat ini masih banyak masyarakat, termasuk kalangan pendidikan, yang memandang museum hanya berfungsi sebagai tempat menyimpan dan memelihara benda-benda peninggalan bersejarah serta menjadi monumen penghias kota. Akibatnya, banyak masyarakat yang tidak sempat untuk meluangkan waktu berkunjung ke museum Permasalahan yang penelitian temukan mengenai didalam Museum Negeri Sumatra Utara antara lain : Banyak masyarakat tidak tau dimana lokasi tempat Museum Negeri Sumatra Utara ,Belum terdokumentasinya data-data pengunjung dengan baik, pengelola Museum dalam mendapatkan laporan harus membuka log-log kunjungan sehingga menyulitkan dalam pembuatan laporan kunjungan ,data -data dalam kunjungan Museum Negeri Sumatra Utara masih secara manual sehingga dapat memperlambat sistem kerja yang berada di dalam Museum Negeri Sumatra Utara.

\section{PENDAHULUAN}

Museum merupakan suatu lembaga yang sifatnya tetap dan tidak mencari keuntungan dalam melayani masyarakat dan dalam pengembangannya terbuka untuk umum, yang mengumpulkan, merawat, meneliti, mengkomunikasikan, memamerkan, pada mulanya museum berfungsi sebagai gudang barang, tempat dimana disimpan benda-benda warisan budaya, bendabenda kuno yang berdebu. Namun fungsi tersebut lama-kelamaan berkembang hingga kearah bidang pendidikan pemanfaatan museum sebagai sumber belajar dapat menjadi program pendidikan yang mendorong kompetensi, belajar menilai, berpikir kritis dan untuk selanjutnya mendorong peserta did berani untuk memberikan sebuah tanggapan-tanggapan serta komentar terhadap nilai-nilai budaya dan peristiwa bersejarah yang terjadi sehingga proses pembelajaran terpusat pada peserta didik[1].

Saat ini masih banyak masyarakat, termasuk kalangan pendidikan, yang memandang museum hanya berfungsi sebagai tempat menyimpan dan memelihara benda-benda peninggalan bersejarah serta menjadi monumen penghias kota. akibatnya banyak masyarakat yang tidak sempat untuk meluangkan waktu berkunjung ke museum. Permasalahan yang penulis temukan mengenai di Museum Negeri Provinsi Sumatera Utara antara lain : Banyak masyarakat tidak tau dimana lokasi tempat Museum Negeri Sumatera Utara, Belum terdokumentasinya data-data pengunjung dengan baik, pengelola Museum dalam mendapatkan laporan harus membuka log-log kunjungan sehingga menyulitkan dalam pembuatan laporan kunjungan, data dalam kunjungan Museum Negeri Provinsi Sumatera Utara masih secara manual sehingga dapat memperlambat sistem kerja yang berada di dalam Museum Negeri Provinsi Sumatera Utara, pemesan karcis masuk Museum Negeri Provinsi Sumatera Utara Masih secara manual[2].

Hal ini menyebabkan penulis tertarik untuk membangun sebuah Aplikasi Sistem Informasi Museum Negeri Provinsi Sumatera Utara berbasis Android yang dapat untuk mempermudah pencarian lokasi. Museum Negeri Provinsi Sumatera Utara tersebut, mempermudah dalam penyampaian informasi yang ada didalam museum tersebut, mempermudah, kepala instansi museum dan tata usaha museum untuk mendapatkan laporan-laporan yang ada di dalam Museum tersebut, data-data pengunjung museum tidak bersifat secara manual dan mempermudah admin dalam mengelolah data-data museum tersebut[3].

\section{LANDASAN TEORI}

\section{a. Aplikasi}

Secara istilah pengertian aplikasi adalah suatu program yang siap untuk digunakan yang dibuat untuk melaksanankan suatu fungsi bagi pengguna jasa aplikasi serta penggunaan aplikasi lain yang dapat digunakan oleh suatu sasaran yang akan dituju. Menurut kamus computer eksekutif, aplikasi mempunyai arti yaitu pemecahan masalah yang menggunakan salah satu tehnik pemrosesan data aplikasi yang biasanya berpacu pada sebuah komputansi yang diinginkan atau diharapkan maupun pemrosesan data yang di harapkan. Pengertian aplikasi menurut Kamus Besar Bahasa Indonesia, "Aplikasi adalah penerapan dari rancang sistem untuk mengolah data yang menggunakan aturan atau ketentuan bahasa pemrograman tertentu[4], [5].

\section{b. Konsep Dasar Sistem Informasi}

Sistem informasi merupakan suatu sistem dalam suatu organisasi yang mempertemukan kebutuhan pengolahan transaksi harian yang mendukung fungsi operasi organisasi [6], [7]yang bersifat manajerial dengan kegiatan strategi dari suatu organisasi untuk dapat menyediakan kepada pihak luar tertentu dengan informasi yang diperlukan untuk pengambilan keputusan[8]. 


\section{c. Museum}

Museum adalah suatu lembaga institusi yang permanen yang melayani kepentingan masyarakat dan kemajuannya, terbuka untuk umum, tidak mencari keuntungan, yang memelihara, meneliti, memamerkan, dan mengkomunikasikan benda-benda nyata dari pembuktian material manusia dalam lingkungannya untuk tujuan studi, pendidikan, dan rekreasi. Museum juga dikenal sebagai pusat preservasi kebudayaan, fungsi ini sangat penting bukan hanya dalam pembinaan pengembangan kebudayaan, juga sebagai sarana membentuk manusia yang utuh. Manusia yang utuh adalah manusia yang mempunyai masa lalu, masa sekarang, dan masa depan. Masa lalu merupakan langkah dasar untuk memahami masa sekarang dan pengembangan pada masa yang akan datang[1].

Museum pada umumnya dikenal dengan sebuah bangunan atau gedung yang menyimpan benda-benda bersejarah warisan budaya patut untuk dilestarikan. Seiiring perkembangan zaman, museum banyak mengalami perubahan dalam fungsinya. yang pada awalnya hanya berfungsi untuk menyimpan berkembang dan bertambah dengan fungsi pemeliharaan, pelestarian, penyajian, dan pameran[2]

Institusi Encyclopædia Britannica membuat sebuah kategori museum secara umum, yaitu:

1. Museum umum ini mengkoleksi banyak jenis-jenis benda yang di dapatnya, tidak hanya satu subjek, dan kadang memuat banyak subjek sehingga kategori museum ini bisa dibilang sebagai museum yang yang memuat banyak hal. Biasanya museum ini dibangun dari era terdahulu, dan dikelola oleh pemerintah.

2. Museum tentang sejarah alam, dan ilmu pengetahuan alam Museum ini memuat tentang sejarah dan ilmu pengetahuan tentang alam, koleksinya terdiri dari burung, mamalia, serangga, tumbuhan, batu, mineral, dan fosil.

3. Museum sains dan teknologi Museum sains dan teknologi lebih berkaitan terhadap perkembangan dan penerapan ide-ide ilmiah dan instrumennya. Seperti museum sejarah dan ilmu pengetahuan alam, museum sains dan teknologi memiliki asal-asul dari benda tersebut didalam deskripsinya.

4. Museum sejarah Kata sejarah kadang digunakan oleh banyak museum yang koleksinya sangat banyak, beberapa museum sejarah seperti museum umum, karena banyak mengkoleksi benda-benda yang berhubungan dengan sejarah alam, sejarah manusia, benda-benda sains, dan kadang seni.

5. Museum seni Museum seni, kadang disebut galeri dibeberapa tempat lebih dikhususkan kepada komunikasi dengan pengunjungnya. Estetika lebih ditampilkan dalam museum, dan menjadi salah satu syarat untuk koleksi museum tersebut.

\section{d. Pengertian Web}

Website adalah: "Web dapat diartikan sebagai kumpulan halaman yang menampilkan informasi data teks, data gambar, data animasi, suara, video dan gabungan dari semuanya, baik yang bersifat statis maupun dinamis yang membentuk satu rangkaian bangunan yang saling terkait, dimana masing-masing dihubungkan dengan jaringan-jaringan halaman (hyperlink)". Web adalah berkas yang dituli sebagai berkas teks biasaya (plain text), yang diatur dan dikombinasikan sedemikian rupa dengan instruksi-instruksi berbasis HTML atau pun XHTML[9], yang kadang - kadang juga turut disisipi dengan berbagai macam bahasa skrip. Berkas web ini nantinya akan diterjemahkan oleh mesin browser dan ditampilkan menjadi sebuah halaman / situs web yang biasa dilihat[10].

Istilah web biasanya sering digunakan di bidang teknologi komputer. Bagi orang - orang yang berkecimpung di dunia ini, istilah web bukanlah istilah yang asing bagi mereka. Akan tetapi, bagi kebanyakan orang awam yang tidak memahami dunia komputer sama sekali, istilah web tentunya merupakan istilah yang sangat awam atau bahkan aneh bagi mereka. Kebanyakan orang awam pada dasarnya sudah pernah melihat dan menggunakan web akan tetapi mereka tidak mengetahui apa itu defenisi web yang sesungguhnya[3].

\section{e. Reservasi}

Pengertian Reservasi Reservasi adalah satu seksi pada departement kantor depan yang tugas dan tanggung jawabnya menangani permintaan pemesanan dari para calon tamu. Sebelum memutuskan bahwa reservasi diterima, petugas perlu memeriksa tersedia atau tidaknya kamar yang diinginkan oleh calon tamu. Cara menentukan ketersediaan kamar [3] antara lain :

1. Forecast Board Desain dan isi papan forecast pada dasarnya sama dengan kalender yang biasanya digantung di dinding dekat dengan petugas reservasi agar dapat dengan mudah melihat informasi pada papan ketika dibutuhkan untuk menjawab permintaan tamu. Papan ini umumnya ditulis untuk periode 4 bulan dan tanggal yang tercantum menunjukkan informasi status kamar. Apabila tidak ada tanggal yang diberi bulatan hitam berarti semua kamar dapat dipesan. Papan forecast diperbaharui secara regular. Reservation Diary adalah buku yang digunakan oleh petugas reservasi untuk memasukkan data-data pemesanan seperti nomor kamar, jenis kamar, nama tamu dan alat. Jam datang dan jam berangkat, harga kamar serta permintaan khusus.

2. Reservation Chart (Booking Chart) Reservation chart adalah bagian reservasi yang digunakan untuk melihat tersedia atau tidaknya kamar yang dipesan oleh tamu. Bagan reservasi dibedakan menjadi dua jenis, yaitu conventional chart dan density chart. Bagan reservasi konvcensional cocok digunakan di hotel kecil dimana jumlah kamar yang dimiliki cukup terbatas. Sedangkan density chart (wall chart) lebih cocok dipakai di hotel besar yang memiliki banyak kamar. Ciri dari bagan konvensional adalah semua nomor kamar dicantumkam, lengkap jenis tempat tidurnya. Pengisiannya adalah nama keluarga tamu ditulis di atas garis panah dengan menggunakan pensil. Bagan ini dibuat dengan basis bulanan. Sedangkan pada density chart tidak dicantumkannomor kamar dan nama tamu tidak ditulis pada bagan. Bagan ini dibuat dalam satu halaman degan basis harian dan berdasarkan jenis tempat tidur. Cara pengisiannya adalah menggunakan pen dimulai dari jumlah kamar yang tersedia dari jumlah angka terbesar sampai yang terkecil, sehingga dapat diketahui jumlah kamar yang masih bisa dipesan hari itu. Ada yang menggunakan garis miring dan ada pula tanda silang.(Swara Dan Periadi.2016) 


\section{HASIL DAN PEMBAHASAN}

Analisis Kebutuhan Perangkat Keras Kebutuhan perangkat keras yang digunakan dalam Aplikasi Sistem Informasi Museum Negeri Provinsi Sumatera Utara Pada aplikasi Sistem informasi Museum Negeri Provinsi Sumatera Utara ini, analisis perangkat perangkat lunak yang digunakan pengembang yaitu:

1. Operating System Windows 1064 bit (Windows 8 dan Windows 7 dapat digunakan)

2. Android Studio yang digunakan untuk membuat aplikasi android, membuat user interface dengan menggunakan xml sebagai layout kemudian memasukan perintah untuk memanggil user interface yang telah dibuat dengan program dalam bahasa pemrograman java.

3. Android Development Tools(ADT) adalah plugin yang digunakan oleh software android studio yang di desain untuk pengembangan aplikasi android.

4. Android 4.4 Kitikat yang digunakan sebagai sistem operasi dari handphone android yang digunakan untuk pengujian aplikasi mobile.

5. StarUML 5.0 salah satu alat bantu yang dapat digunakan dalam bahasa pemrograman yang berorientasi objek.

Use Case berfungsi untuk menggambarkan secara grafis perilaku software aplikasi atau menggambarkan fungsionalitas yang diharapkan dari sebuah sistem, yang ditekankan adalah "Apa" yang diperbuat sistem, dan bukan "Bagaimana" melakukannya. Secara garis besar Use Case adalah merancang sebuah Aplikasi Sistem Informasi Museum Negeri Provinsi Sumatera Utara Berbasis Android dapat dilihat seperti pada Gambar 1 berikut:

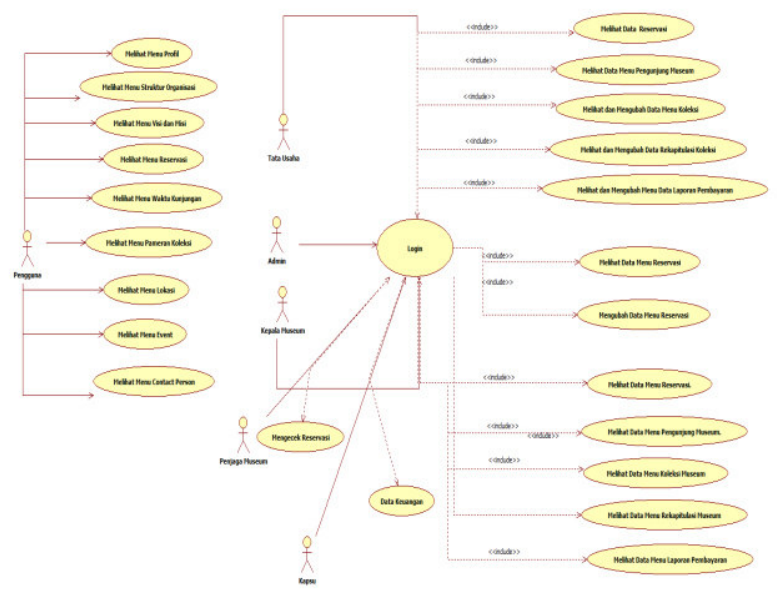

Gambar 1. Use Case Diagram Museum Negeri Provinsi Sumatera Utara

Class diagram menggambarkan struktur statis dari kelas dalam sistem dan menggambarkan atribut, operasi dan hubungan antara kelas. Class diagram dapat dilihat seperti pada Gambar 2 berikut:

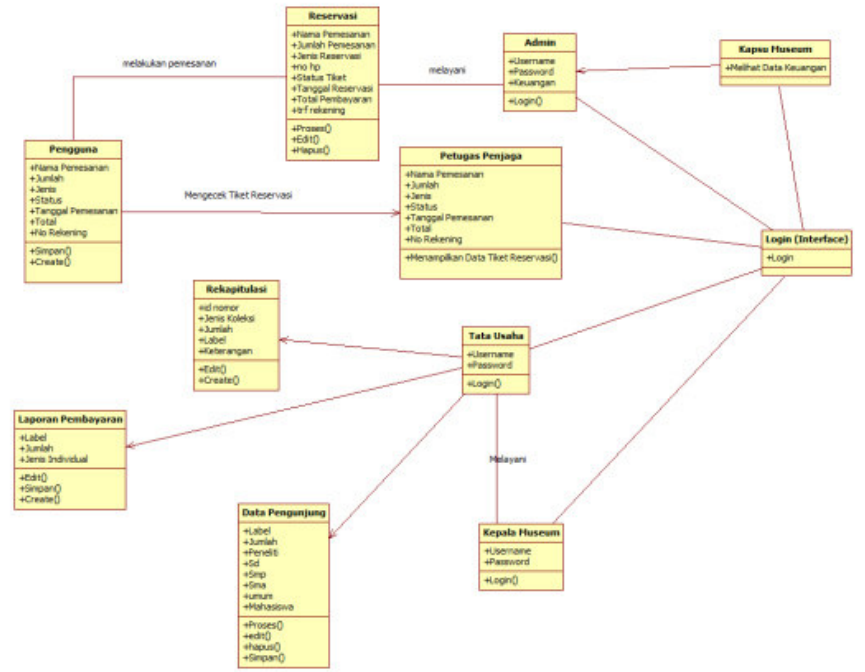

Gambar 2. Class diagram

\section{b. Implementasi}


Halaman Beranda merupakan tampilan awal saat sistem dijalankan, dimana pada halaman ini akan ditampilkan informasi menu beranda, menu tentang, menu inforamasi, menu event, menu reservasi, menu koleksi, Adapun Halaman beranda dapat dilihat seperti pada Gambar 3 berikut:

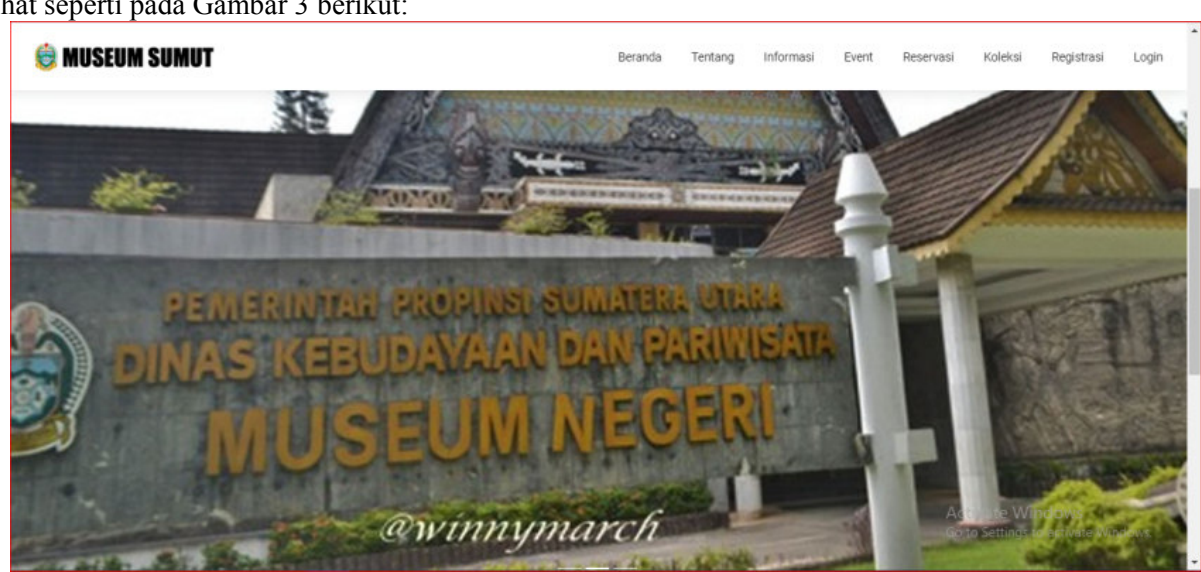

Gambar 3. Tampilan Halaman Beranda

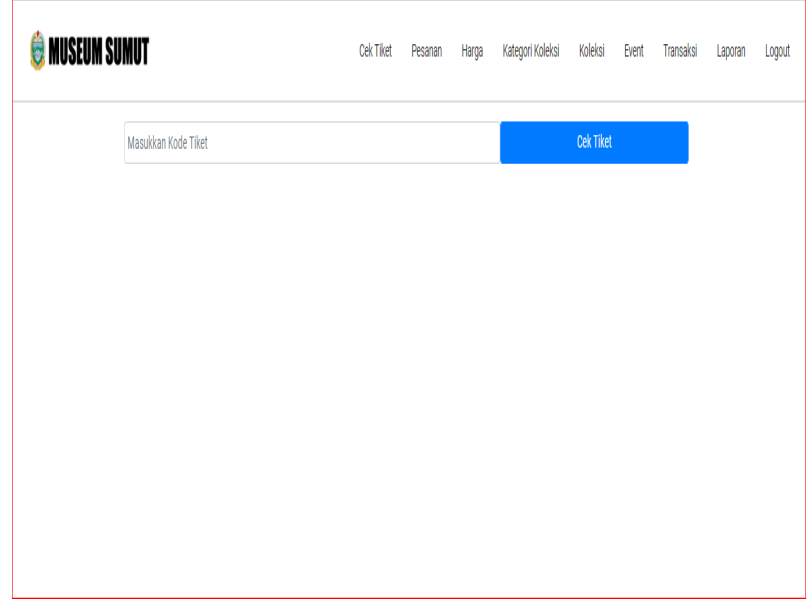

Gambar 4. Tampilan Halaman Utama Admin

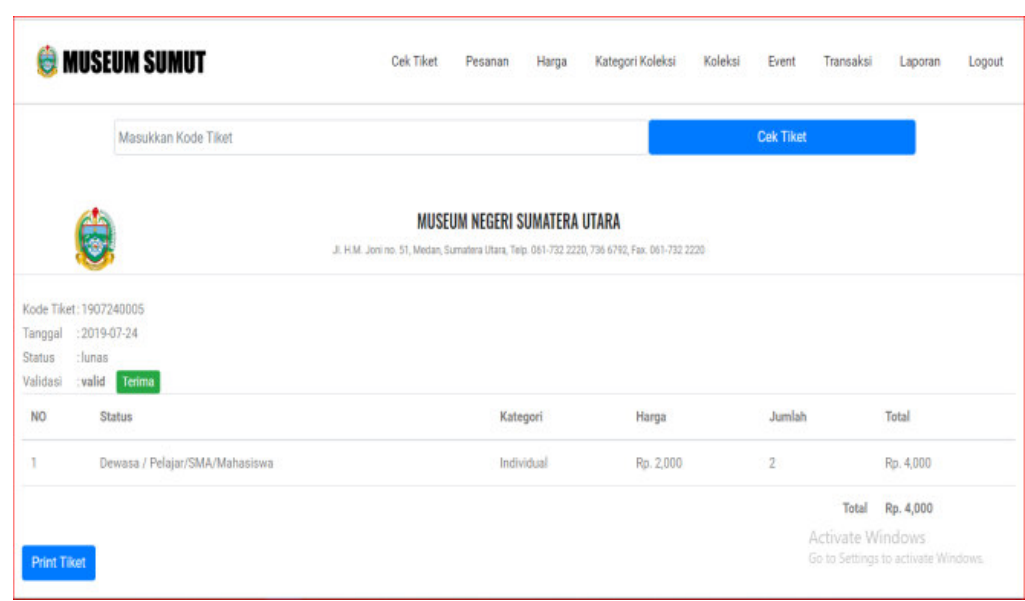

Gambar 5. Tampilan Halaman Admin Cek Tiket 


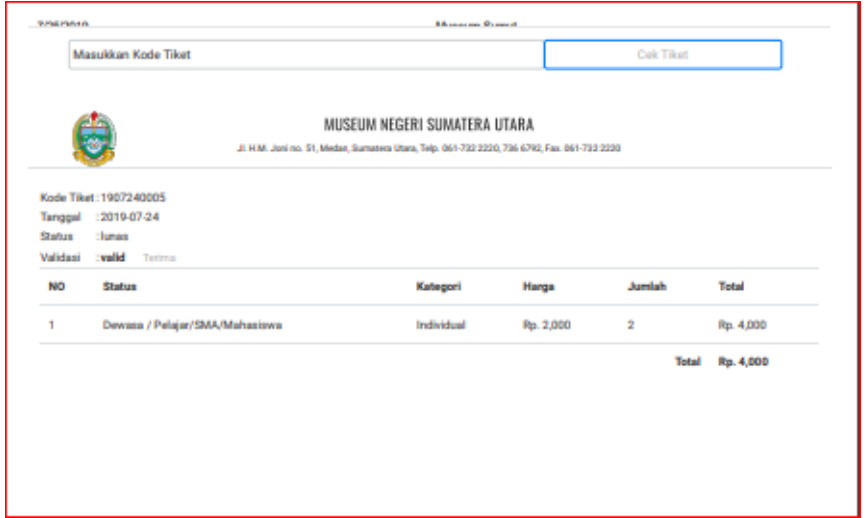

Gambar 6. Tampilan Halaman Print Cek Tiket

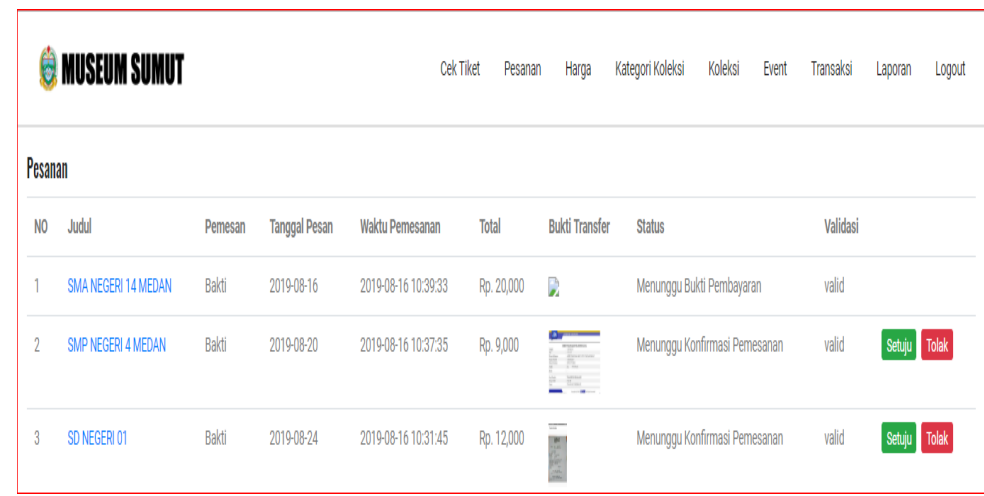

Gambar 7. Tampilan Halaman Output Pesanan

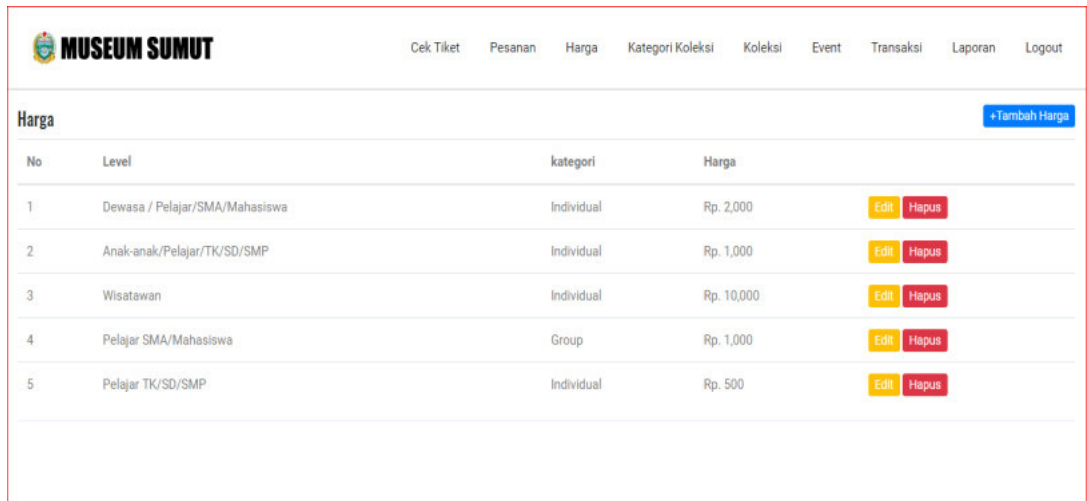

Gambar 8. Tampilan Utama Harga

\section{KESIMPULAN}

Dalam Perancangan Aplikasi Sistem Infornasi Museum Negeri Provinsi Sumatera Utara Berbasis Android, maka diambil kesimpulan yaitu : dengan adanya aplikasi sistem informasi museum ini dapat membantu pengunjung museum dalam membeli karcis masuk secara online, dengan adanya aplikasi sistem informasi museum ini sehingga mempermudah bagi pihak Museum Negeri Provinsi Sumatera Utara dalam mengelolah data-data museum tersebut, dan dengan adanya sistem ini sehingga dapat di implementasikan ke Museum Negeri Provinsi Sumatera Utara

\section{DAFTAR PUSTAKA}

[1] Suraya and M. Sholeh, "E-MUSEUM SEBAGAI MEDIA MEMPERKENALKAN CAGAR BUDAYA DI KALANGAN MASYARAKAT." nstitut Sains \& Teknologi AKPRIND Yogyakarta, 19-Jan-2016.

[2] A. J. . Wibowo, "Persepsi Kualitas Layanan Museum di Indonesia: Sebuah Studi Observasi," J. Manaj. Prasetiya Mulya Sch. Bus. Econ., vol. 15, no. 1, pp. 13-40, 2015.

[3] S. A. Sitorus and E. P. Malau, "Sistem Informasi Reservasi Hotel Pada GM. Marsaringar Balige Berbasis Android," MEANS (Media Inf. Anal. dan Sist., vol. 2, no. 1, pp. 52-57, Jun. 2017.

[4] H. M. Jogiyanto, Analisis dan Desain (Sistem Informasi Pendekatan Terstruktur Teori dan Praktek Aplikasi Bisnis). 
Yogyakarta: Penerbit Andi, 2017.

[5] E. Kartini and P. Silitonga, "Sistem Informasi Wisata Kuliner di Kota Medan Berbasis Web," MEANS (Media Inf. Anal. dan Sist., vol. 2, no. 2, pp. 139-145, 2018.

[6] M. Y. Panjaitan and R. Damanik, "Sistem Informasi Catholic Center Medan Berbasis Web," MEANS (Media Inf. Anal. dan Sist., vol. 2, no. 2, pp. 134-138, Jan. 2018.

[7] P. Sihombing and S. Pakpahan, "Perancangan Sistem Informasi Kepegawaian Pada Badan Kepegawaian Dan Pendidikan Daerah Kabupaten Dairi," Media Informasi Analisa dan Sistem, 2016. [Online]. Available: http://ejournal.ust.ac.id/index.php/Jurnal_Means/article/view/9/9. [Accessed: 02-Feb-2020].

[8] T. Limbong and I. . Suardana, "Implementasi Konsep 'BETAH' dalam Pelaksanaan Ujian Akademik Penerimaan Polri Terpadu Polda Sumatera Utara berbasis Komputer dan Manual,” Media Inf. Anal. dan Sist., vol. 3, no. 1, pp. 611, 2018.

[9] T. Limbong, "PERANCANGAN SISTEM INFORMASI KEHADIRAN MENGAJAR DOSEN," Pelita Inform. Inf. dan Inform., 2012.

[10] J. O. Sembiring and S. Pakpahan, "Sistem Informasi Pemesanan Dan Penjualan Barang pada Pintera Kreativ Berbasis Web," MEANS (Media Inf. Anal. dan Sist., vol. 2, no. 2, pp. 146-152, Jan. 2018. 